\title{
Patronage and Elections in U.S. States ${ }^{1}$
}

\author{
Olle Folke \\ School of International and Public Affairs \\ Columbia University \\ IFN \\ Shigeo Hirano \\ Department of Political Science \\ Columbia University \\ James M. Snyder, Jr. \\ Department of Government \\ Harvard University \\ NBER
}

September, 2010

\footnotetext{
${ }^{1}$ We thank Don Green, Ken Shepsle, and seminar participants at MIT and Stockholm School of Economics for their helpful comments.
} 


\begin{abstract}
This paper examines whether control of patronage jobs significantly increased a political party's probability of winning elections in U.S. states. We employ a differences-in-differencs design, exploiting the fact that there is considerable variation in the dates different states adopted civil service reforms. We find evidence consistent with the hypothesis that political parties in U.S. states were able to use patronage to increase the probability of maintaining control of their state legislatures and statewide executive offices. We also find evidence that an "entrenched" party in power for a longer time period can use patronage more effectively than a non-entrenched party. We consider several alternative hypotheses that might plausibly account for the patterns in the data, but find no evidence to support them.
\end{abstract}




\section{Introduction}

Does the control of patronage significantly increase a political party's probability of winning elections? Perhaps surprisingly, at least for the U.S. we do not know the answer to this question.

Theoretically, it seems hard to believe that the answer could be anything but "Yes." Patronage jobs constitute a valuable resource for the party in power. As Pollock (1937, p. 32) notes: "Employees who are politically appointed are naturally expected to attend political meetings, make speeches, canvass voters, and do all the other things involved in political activity." Parties also use patronage for "raising campaign funds through the assessment of public employees. 'Two per cent clubs' manage to squeeze large sums of money out of politically appointed employees to help defray campaign costs. The public pay roll is thus used in an indirect way to pay party expenses." Maranto and Johnson (2007, p. 79) states the claim succinctly: "Before the 1950s, U.S. political appointments were primarily to help the incumbent party win elections as 'spoils' patronage." 1

On the other hand, electoral considerations are not necessarily the primary factor affecting party leaders' decisions regarding how to distribute patronage (e.g. Sorauf, 1959; Wilson, 1961; Johnston, 1979). Many patronage jobs may be used to maintain party organizations or be consumed as rents. Party bosses must often provide loyal lieutenants or key factional leaders with patronage, even if this is not the most efficient allocation from a vote maximization perspective, in order to maintain their position as bosses. Surveys of patronage recipients often find that they were not particularly active in politics either before or after receiving their jobs (e.g. Sorauf, 1956; Johnston, 1979). ${ }^{2}$ Furthermore, by not allocating jobs to maximize votes, patronage could even have a negative effect on a party's electoral support by alienating those who do not receive jobs. ${ }^{3}$ Pollock (1937, p. 30) writes that

\footnotetext{
${ }^{1}$ In a similar but less critical vein, Key (1964) notes: "The patronage system may be considered, too, as a method of financing party activity. The operation of a party organization requires the services of many men and women... Though much of this work is performed by unpaid volunteers, their efforts are not adequate. Indirectly, a considerable part of party expense is met by the public treasury, and the chief means of channeling public funds to party support is through the appointment of party workers to public office."

${ }^{2}$ In Sorauf's (1956) study of Centre County, Pennsylvania, only $43 \%$ claimed to have engaged in any campaign work for the party.

${ }^{3}$ In his study of New Haven, Johnston (1979) found that patronage was severely miss-allocated from a vote-maximizing point of view.
} 
"for every appointment which is made, perhaps a dozen disappointed persons are made to grumble - the one appointed in many cases becoming an ingrate." 4

This paper provides evidence that patronage does - or did - help U.S. parties in power retain power. To our knowledge, this is the first paper to do so. We study the U.S. states over a one-hundred-and-ten year period, 1885-1995. Within this period there was large variation in the timing of civil service reform across states. Illinois and Wisconsin adopted general civil service laws in 1905, while Mississippi and Montana did not do so until 1976. The period studied therefore includes about 20 years before 1905 and 20 years after $1976 .^{5}$ We exploit this variation to estimate the degree to which control over patronage jobs affected a political party's probability of winning future elections.

In the first set of empirical analyses in this paper, we ask two simple questions: If a party wins control of the state legislature at time $t$, does that party have a higher probability of maintaining control of the legislature over the next few elections, at times $t+1, t+2$, etc.? Second, and more importantly, is the probability of maintaining control of the legislature over the next few elections even higher under a patronage system then it is after the adoption of civil service reforms? We also study elections to statewide executive offices at $t+1, t+2$, etc., in addition to control of the state legislature.

Our estimates indicate that the answer to both questions is "Yes," and that the effects of patronage are large. Consider a party that barely wins control of the state legislature at time $t$. The probability that this party continues to control the legislature over the next four elections is about 25 percentage points higher under a patronage system than under a civil service system. We find a similarly large difference in the probability of winning future

\footnotetext{
${ }^{4}$ More recently, Trounstine (n.d.) found that, conditional on running for re-election, mayors and city council members in her sample were less likely to win in cities with large municipal workforces. As she notes, in most cities most employees were covered by civil service law or union contracts. Restricting the attention to cities where municipal employees were not unionized (in 1986) reversed the sign of the coefficient, but it is statistically insignificant.

${ }^{5}$ New York and Massachusetts adopted civil service laws very early on - in 1883 and 1885 respectively - around the time the federal government adopted the Pendleton Act. West Virginia was the last state to adopt a general civil service law, in 1989. Since these were relatively large outliers, we do not try to include long pre-reform or post-reform periods for these states. Attempting to include a long pre-reform period for New York and Massachusetts would be especially difficult, since it would take us into Reconstruction, and also well into the era when most states still used party ballots rather than a secret ballot. These likely had significant effects of their own on incumbent parties, and incorporating them would significantly complicate the analysis.
} 
elections for statewide executive offices. Overall, the evidence is strongly consistent with the hypothesis that political parties in U.S. states were able to use patronage to increase the probability of maintaining control of their state legislatures and also to increase the probability of winning other statewide offices.

In the second part of the paper, we examine whether parties that control the legislature for several years are better able to take advantage of patronage. We refer to these parties as entrenched parties. Scholars have speculated that entrenched parties have an advantage through the patronage system. For example, Sorauf (1959, p. 118) writes:

$[\mathrm{J}]$ ust as it takes money to make money, it takes political power to achieve greater power. The party long out of office and desperately in need of new reservoirs of strength is precisely the party that, should it suddenly find itself in office, would be least able to use patronage for rebuilding. Weak parties lack the discipline, the trained leadership, and the surplus of potential jobholders to use the system to their maximum advantage.

However, there is little systematic evidence that experience controlling the government confers an additional electoral advantage.

Thus, we ask another simple question: Is the higher probability of maintaining control of the legislature over the next few elections we observe for winning control of the legislature at time $t$ under patronage even higher if the winning party also controlled the legislature for several years prior to $t$ ?

Our estimates indicate that entrenched parties have an electoral advantage under the patronage system relative to non-entrenched parties. Under a patronage system, the probability an entrenched incumbent maintains control over the subsequent elections is more than 30 percentage points higher than for a non-entrenched party. After the introduction of civil service, we find little evidence that entrenched parties maintained their electoral advantage.

We also provide some evidence that this entrenched party advantage under patronage may be related to entrenched parties' ability to win "very close" elections. Prior to the general civil service reforms, entrenched parties won about three out of four close elections. Under civil service the entrenched parties did not have any advantage in winning these close 
elections. It is difficult to know why this is the case, but one possibility is that incumbent parties are selective in using the electoral resources available to them under a patronage system, and use these resources especially in elections that are expected to be close. Another possibility is that outright vote fraud is associated with patronage regimes.

\section{Data and Background}

\subsection{Main Variables}

Our main dependent variables are election outcomes: party control of state legislative houses and party control of various statewide executive offices. ${ }^{6}$ Data on the share of seats won by each party in each state legislature are from Dubin (2007). Data on the share of statewide offices won by each party are from a variety of sources (see Ansolabehere and Snyder, 2002, for details).

The main independent variables are dummy variables indicating which party controls each legislative chamber, and a dummy variable indicating which states have adopted general civil service reforms and which have not. The data on civil service reform were discussed below. The legislative control dummy is constructed from Dubin (2007). We also conduct analyses that incorporate control of the governor's office in addition to control of the legislature. We describe these in more detail in the next section.

Before proceeding to the data analysis we discuss two issues. First we provide an overview of civil service reform at the state level to highlight the sources of variation in one of our key independent variables. Second, we discuss our reasons for focusing attention on state legislatures when thinking about the partisan value of patronage.

\subsection{The Spread of General Civil Service Laws in U.S. States}

Most students of U.S. politics are taught at least the broad outlines of civil service reform at the federal level - that it began in 1883 with the Pendleton Act and then steadily expanded over the next four decades until, by 1922, about $80 \%$ of the federal employees were under

\footnotetext{
${ }^{6}$ The offices we study are governor, lieutenant governor, secretary of state, attorney general, treasurer, auditor, controller, comptroller, school superintendent, public utility commissioner, corporation commissioner, agricultural commissioner, land commissioner and insurance commissioner.
} 
the civil service. The history of reform at the state and local level is more obscure, however. One basic fact that does not appear to be widely known is that most states implemented a general civil service law relatively recently. Only nine states had a general civil service law in 1936, and a majority of the states did not adopt such a law until after $1950 .{ }^{7}$ Figure 1 shows the timeline. ${ }^{8}$ Thus, comprehensive civil service reform at the state level lagged behind the federal civil service by many decades. Unlike primary elections, the direct election of U.S. senators, and women's suffrage, it was not even a progressive-era reform. ${ }^{9}$

In the 1930s the federal government pressured all states to adopt limited civil service reforms. Specifically, in 1939 an amendment to the Social Security Act required states to enact merit-based personnel systems for state and local government employees working in welfare, health, and unemployment compensation agencies, as a condition for receiving federal grants-in-aid. ${ }^{10} \mathrm{~A}$ few states enacted a more sweeping reform around this time, but most did not (see Figure 1).

Figure 2 makes it clear that these partial reforms were quite limited in scope. For each state that passed a general civil service law after 1960, we calculated the percentage of fulltime state employees covered under the state's civil service, for the 11 years before and after the passage of the law. ${ }^{11}$ Figure 2 shows these percentages as well as the average (the solid line). On average, prior to the passage of a general civil service law, less than $20 \%$ of the state employees were covered by civil service systems. After the passage of such a law, this jumped to an average of more than $60 \%$.

\footnotetext{
${ }^{7}$ Texas never passed a general civil service law.

${ }^{8}$ The data on civil service adoption are from The Book of the States (various issues), the Civil Service Assembly of the United States and Canada (1940) and Aronson (1979).

${ }^{9}$ Berry (2000, p. 193) notes that around the turn of the 20th century "the drive for civil service reform in other states bogged down as well. Bills focused on reform were introduced in Pennsylvania, Maryland, New Jersey, Ohio, Virginia, Rhode Island, Indiana, Illinois, Wisconsin, Missouri, and California but failed to be enacted into law."

${ }^{10}$ The states were required to comply by January 1, 1940. Under the 1935 Social Security Act, the Social Security Board had tried to insist that state welfare and unemployment compensation agencies establish personnel standards, but these were evidently not very effective. In Arkansas, for example, "Despite federal personnel standards, the State Department of Public Welfare became a patronage bonanza. The expansion of government services enlarged the army of public employees, which in turn enhanced the spoils system" (Holley, 1986, p. 294).

${ }^{11}$ Data on the number of employees covered are from The Book of the States (various issues), and the data on total state employment are from the State Distribution of Public Employment, published by the Bureau of the Census. We restrict the attention to the states that passed their general civil service law after 1960 because the data on the number of employees covered begin in 1955.
} 
The scattered evidence available shows that for the general civil service laws passed before 1960 the increases in coverage were of a similar magnitude. The 1905 civil service law in Wisconsin covered about 52\% of the state employees in 1908 and $63 \%$ in 1918; the 1921 law in Maryland covered about 69\% in 1925; the 1908 law in New Jersey covered about 80\% by 1922; the 1937 law in Arkansas covered about 67\%; the 1937 law in Michigan and the 1939 law in Rhode Island both covered more than 80\% in 1940; the 1939 laws in Alabama and Minnesota each covered about 80\%, and the 1940 law in Louisiana covered about 85\% of the state employees. All of these represented large changes since the baseline coverage rates were zero.

Figure 2 shows that in most states, the percent of employees covered is almost a step function, rising sharply with the passage of a general civil service reform. In a few states the expansion of the civil service was more gradual. For example, in Pennsylvania the first law passed soon after the Social Security Act mandate mentioned above. The governor extended the civil service by an executive order in 1956, adding about 13,000 positions and bringing the percentage of state employees covered to about 40\% by 1961. In 1963 the state passed a major reform that increased the percentage covered to over $50 \%$.

One further issue must be addressed. The Hatch Act prohibits federal government employees from engaging in certain political activities. Amendments to the Hatch Act in 1940 extended the provisions of the Act to any state and local government employees who work in areas financed by federal government loans or grants. ${ }^{12}$ State and local employees covered by the Hatch Act may not run for public office in partisan elections, use their official authority to interfere with or affect the results of an election or nomination, or directly or indirectly coerce contributions from subordinates in support of a political party or candidate. They are allowed to run for public office in nonpartisan elections, campaign for and hold office in political clubs and organizations, actively campaign for candidates for public office in partisan and nonpartisan elections, and contribute money to political organizations and attend political fundraising functions. ${ }^{13}$

\footnotetext{
${ }^{12}$ More specifically the amendments state that the Hatch Act would cover an "individual employed by a State or local agency whose principal employment is in connection with an activity which is financed in whole or in part by loans or grants made by the United States or a federal agency."

${ }^{13}$ Violations of Hatch Act provisions by state or local employees are punished by a minimum 30-day
} 
We do not know whether the extension of the Hatch Act had a large or small impact. Many scholars argue that violations were common. For example, McKean (1949, 322-323) writes:

[I]t does not take much acquaintance among politicians to discover that they [the Hatch Acts] are widely evaded or violated... In a vast variety of subtle ways it is possible for an employee to use his official discretion to influence elections, and he can covertly take a fairly active part in politics... Some states have 'Little Hatch Acts,' and others have provisions in their civil service laws to the same effect. Like the federal statutes, these too are often evaded and violated.

States sometimes choose to pay fines rather than dismiss employees for violations of the act. For example, Utah paid $\$ 42,000$ in fines in 1960 rather than fire three employees of the State Highway Department for urging department employees to contribute to a Republican fund-raising dinner (Gordon et al., 1962).

A final consideration is public sector collective bargaining. Most states introduced provisions regarding collective bargaining in the latter half of the 20th century long after they had already introduced civil service reforms. Klingner (2006) notes, collective bargaining only "began in earnest in the public sector in 1960s and 1970s." ${ }^{4}$ We include some robustness checks and do not find evidence that the introduction of collective bargaining had a significant impact on the incumbent party's likelihood of winning future elections.

\subsection{Why Focus on State Legislatures?}

As noted above, in analyzing the partisan advantages of patronage we focus heavily on control of the state legislature. We do this for several reasons.

First, in all states the legislature holds the ultimate power to make all laws, and the legislature also holds the power of the purse. Thus, all other state officials must bargain with the legislature to get anything done. This fact is noted and discussed most frequently

suspension without pay, and possibly by removal of the employee. If the employing agency refuses to punish the employee, then it may lose federal funds equal to two years of the employee's salary.

${ }^{14}$ See also Kearney (2001). 
with regards to gubernatorial leadership - how governors obtain, or fail to obtain, legislative approval of their policy agendas. Zink (1951, p. 775) lays out the logic clearly:

It is very difficult for a governor to carry through a very ambitious program of legislation in most states without making some use of the patronage power. If a different type of person is elected to the legislature at some future time it may not be necessary to resort to offering jobs, promising political advancement and otherwise dangling favors before the eyes of those who make the laws. But under the present setup, the majority of those who get themselves elected to the seats in a state legislature expect to be rewarded for their services beyond the salary and honor attached to their office.

In a similar vein, Jewell (1962, p. 120) states that, "In most states the dispensing of jobs offers the governor one of his best opportunities to influence legislators; this is more important to most governors than to the President." He also notes that, "In two-party states patronage is likely to be one of the factors in maintaining party discipline," while in one-party states "patronage may become the crucial factor in securing his legislative program" (p. 120). Jacob and Vines (1965, p. 197) echo this, stating, "In the one-party states where party appeals in themselves are insufficient, the astute use of patronage and pork is indispensable in securing support for the governor's program." And Nixon (1948, p. 417) writes, "A governor bent on such a purpose [influencing the legislature] must make use of large amounts of both wisdom and patronage to succeed." 15

Second, most U.S. states have a "plural executive." In most states through most of the period we study, the lieutenant governor, secretary of state, attorney general, treasurer, auditor or comptroller, and public school superintendent were all separately elected officials. In many states one or more of the following commissioners were elected: public utilities, agriculture, insurance, state lands, mines, taxes, highways, and public works. Prior to the adoption of the civil service law, these officials typically controlled the patronage jobs

\footnotetext{
${ }^{15}$ This was even true at the federal level, as Kaufman (1956, p. 1068) notes: "Federal patronage ... was distributed largely through Senators and Representatives, hopefully in return for the legislators' voters on issues in which the Presidents were interested ... In short, the patronage system strengthened party leaders and legislators more than it did executives. Thus the appointing power of the President was bargained away."
} 
under their administration. They would often bargain separately with the legislature in the allocation of this patronage. Carpenter and Stafford (1936, p. 49.) note that, "The governor is seriously handicapped by the dispersion of executive power among constitutional officers, over whose appointment and removal he seldom has any control." ${ }^{16}$ Florida took this to an extreme, employing a "cabinet" government in which the governor shared voting power with other elected statewide officials. ${ }^{17}$ Other states curtailed the governor's budgetary authority as well. For example, until 1950 the South Carolina State Budget and Control Board was comprised of three members: the governor, the chairman of the Senate Finance Committee, and the chairman of the House Ways and Means Committee. In 1950 it was expanded to five members, with the State Treasurer and Comptroller General added. Even then, as Larson (1968, p. 83) notes, "Because the Governor is limited constitutionally to a four-year term, he is usually the least experienced member of the board."

In some states administration was further decentralized by the existence of numerous independent boards or commissions, whose heads were chosen by the governor with the consent of the state senate, or in some cases directly by the legislature. These boards had overlapping terms so the governor could usually only appoint a minority of the members during his term. According to Carpenter and Stafford (1936, p. 58-59), the results of the plan were that, "It is an excellent system through which to safeguard the state services from dislocation which results from frequent changes in the political officers of the government, but it denies to the governor any real responsibility for the conduct of administration." Thus,

\footnotetext{
${ }^{16}$ Cleary (1960, p. 165-166) describes the situation in Mississippi: "The Mississippi governor, for example, has little administrative power. A majority of the leading department heads, including the attorney general, the secretary of state, the treasurer, the auditor, and the chairman of the highway commission, are elected by popular vote. Such officials often acting independently of the governor, control both job and contract patronage in their agencies because Mississippi has neither a central personnel office nor a central purchasing system... It is jobs and contracts for his district - especially for his supporters - that are most effective in bringing a balky legislator into line, but the governor of Mississippi has a difficult time providing either."

${ }^{17}$ Roady and Dauer (1968, p. 42) describe the situation: "The six elected cabinet officers in Florida along with the Governor, constitute some fifty-five boards or commissions, which act as the chief administrative body of many departments and functions of the state government. For example, even the state budget is prepared, not by the Governor, but by the Governor and the cabinet as ex officio members with an equal vote on the State Budget Commission. Public safety and numerous other functions are under this ex officio cabinet arrangement. Not all of the ex officio boards include all of the cabinet; some, in fact, do not even include the governor. Partly because of this constitutional situation, the influence of the Governor over the Legislature is rather severely circumscribed. He can use neither patronage nor budgetary largess to dominate the Legislature. The Legislature appropriates in great detail, even to the point of specifying the salaries of numerous individual officials."
} 
"the governor of New Jersey continues to be the chief executive in name more than in fact." This plan was taken to its extreme in New Jersey (it is often called the "New Jersey plan"), but was emulated in Connecticut, Michigan and Wisconsin.

Most scholars and observers argue that over the long term the power of the governor has tended to increase relative to that of the legislature. But this trend is difficult to measure objectively, and it seems impossible to identify, for each state, clear "break-points" before which the legislature was dominant and after which the governor was dominant. We attempt to deal in a crude way by cutting the data roughly in half, into "early" and "late" periods.

Third, for most of U.S. history individual state legislators did not have the resources to run "personal" re-election campaigns, and were forced instead to rely on the party organization and the popularity of prominent party leaders. Even today this is true in many states. Governors, on the other hand, can often run lavish personal campaigns that are largely independent of their parties. They receive extensive media coverage, and can raise large campaign war-chests. Legislators therefore have a greater incentive than governors to use patronage for partisan electoral gain. Keefe (1966, p. 45-46) writes:

Few matters have more intrinsic interest for legislatures than matters of personnel. For one thing, policy may be at stake... More important, usually, is patronage. Where state merit systems are comprehensive, legislatures may see the civil service as a vast wasteland. But when jobs can be made available for supporters, legislative interest runs high; access to patronage may prove to be a critical resource in the life of the legislator.

Moreover, in the era of strong party organizations most observers emphasized the importance of county organizations, and state legislators have tended to have close ties to their counties. ${ }^{18}$ The end result, at least for a state with enough desirable patronage jobs, is predictable: "The patronage agency, then, is under continuing pressure by the county chairmen and some state

\footnotetext{
${ }^{18}$ For example, Merriam and Gosnell (1949, p. 192) write: "In the actual scheme of things the county looms large as a factor in routine political leadership and direction, especially on the organizational side... County leaders who have depended on spoils of various types, such as interest on public funds, fees, contracts, and patronage, have had practically a free hand, and groups of powerful leaders have combined to govern states... The county boss and county ring or rings have been factors of the first importance in the maintenance of a party system of state control."
} 
legislators for jobs and is always well supplied with applicants for certain kinds of positions. The problem faced by the patronage administrator, therefore, is how to allocate his resources in the face of demands placed upon him" (Tucker, 1969, p. 82). Merriam and Gosnell (1949, p. 211) echo this assessment, especially with respect to non-urban machines: "The rural boss system is based chiefly upon patronage and minor spoils of various types, and it connects with the state organization through the state legislature, where votes are needed."

\section{The Effect of Patronage on Election Outcomes}

\subsection{Specification}

As noted in the introduction, under a patronage system the party that wins control of government should be able to use patronage to win future elections. We assess this prediction empirically by asking the following questions. Suppose that a party wins control of the legislature in state $s$ in the election at time $t$. What is the probability that this party continues to control the state legislature by winning the elections at times $t+1, t+2, t+3$, and so on? Is this probability higher if state $s$ is under a patronage system rather than a civil service system?

A party controls the legislature after an election at time $t$ if it holds majorities in both houses. ${ }^{19}$ Our basic specification is simple:

$$
V_{s t}=\alpha_{s}+\gamma_{t}+\beta_{1} P_{s t}+\sum_{k=1}^{K} \beta_{2 k} M_{s t}^{k}+\sum_{k=1}^{K} \beta_{3 k} P_{s t} M_{s t}^{k}+\epsilon_{s t}
$$

The dependent variable $V_{s t}$ is the future election outcome under study from the point of view of the party that controls the legislature in state $s$ at time $t$. The $\alpha_{s}$ 's and $\gamma_{t}$ 's are state and year fixed-effects, respectively. ${ }^{20}$

The variable $M_{s t}$ is the share of lower house seats won at time $t$ by the party controlling the state legislature at time $t$, minus $50 \%$. This captures the size of the majority party's

\footnotetext{
${ }^{19}$ If control is split across the chambers, or if there is an exact tie in one chamber and the major legislative positions were divided, then neither party controls the legislature at time $t$. These cases are dropped from the analysis.

${ }^{20} \mathrm{We}$ also ran specifications where we allow the state fixed-effects to vary over three different electoral realignment periods: 1880-1895, 1896-1931, and 1932-1990. The results on the variables of interest are similar to those reported below.
} 
strength among voters at time $t$. In some specifications we set $k=3$, to capture potential non-linearities in the relationship between voter support and the probability of winning. In other specifications we impose a linear relationship, and set $k=1$. We focus on the lower chamber, because upper house election results are a relatively noisy measure of voter support. Upper houses are small, so seat shares are lumpy. The median number of seats in the upper chambers in our sample is only 35 and the average is 37. More importantly, in most states upper chambers have staggered four-year terms, with only half of the seats up for election every two years. Thus, it may easily be the case that the 17 or 18 seats up for election in any given year are not representative of the state as a whole. By contrast, lower chambers are relatively large, with a median size of 100 seats. And, almost all lower chambers have two-year terms in which all seats are up for election every two years. ${ }^{21,22}$

We allow the slope on $M_{s t}$ to differ under patronage and civil service, because we expect the effects of patronage on winning future elections to be larger when $M_{s t}$ is smaller. In a state where political competition is lopsided due to the distribution of voter partisanship - e.g., a southern state before 1964 with a disproportionate number of loyal Democratic voters, or one of the northern states before 1930 with a disproportionate number of loyal Republicans - the dominant party will win at time $t$, and at times $t+1, t+2$, etc., regardless of whether or not they have access to patronage. In more competitive situations, however, where both parties have a reasonable chance of winning, control of the patronage apparatus may make a difference. And a close election at time $t$ is a good indicator of a relatively competitive situation.

The main variable of interest is $P_{s t}$, a dummy variable defined as $P_{s t}=1$ if state $s$ is operating under a patronage system at time $t$ and $P_{s t}=0$ if state $s$ is operating under a

\footnotetext{
${ }^{21}$ The exceptions are as follows: Alabama switched to four-year terms after 1901, Maryland switched to four-year terms after 1923, Mississippi switched to four-year terms after 1890, and Louisiana and North Dakota had four-year terms for the entire period. Also, a few states had one-year terms: Connecticut before 1886, Massachusetts before 1920, New Jersey before 1948, New York before 1938, and Rhode Island before 1912.

${ }^{22}$ To deal with the fact that chambers differ in size across states, we also ran specification in which we replaces $M_{s t}$ with a Margin Category measure that is a combination of seat shares and the absolute number of seats won. For example, Margin Category $=k$ in a given chamber if either: (i) a party's share of the seats in the chamber is between $50-k$ and $50+k$ percent, or (ii) a party is $k$ seats from winning or losing a majority and the party's share of the seats is between $50-2 k$ and $50+2 k$ percent. The results using the Margin Category variable are similar to those reported below.
} 
general civil service law. If $\beta_{1}>0$, then the party controlling the legislature at time $t$ is more likely to win subsequent elections under a patronage regime than under the civil service when the lower house is evenly divided. ${ }^{23}$

In addition, in some specifications we focus on cases where the majority party in state $s$ at time $t$ was determined by a relatively "close" election. These are the cases where we expect patronage to matter the most. ${ }^{24}$ Because we use narrow windows to define "close" elections, we do not include state fixed effects, year fixed effects, or lower house seat share in these specifications.

We study four dependent variables: (i) a dummy variable indicating that the party in control at $t$ won control of the state legislature in each of the subsequent 8 years beginning at $t+1$; (ii) the share of statewide offices won by the party in control at $t$ during the 8 years beginning at $t+1$; (iii) a dummy variable indicating that the party in control at $t$ won control of the state legislature in the subsequent 4 years beginning at $t+1$; and (iv) the share of statewide offices won by the party in control at $t$ during the 4 years beginning at $t+1$. The first two variables capture relatively long-term effects. We use an eight-year window because most upper chambers in state legislatures have four-year terms and most statewide offices are four-year terms - thus, for most states the variables cover two full election-cycles. Also, variable (i) captures four lower-house elections. The second two variables capture more short-term effects - typically, one full election cycle in the state legislature and the next election of statewide officials. ${ }^{25}$

\footnotetext{
${ }^{23}$ By using a dummy variable for elections under the patronage system we are ignoring the heterogeneity in the number of patronage appointees across states. When we focus on the period from 1955 to 1982 and use the fraction or total number of employees covered under civil service the results generally have the same sign as the patronage dummy but are less stable and are often not statistically significant. This may reflect some measurement error - e.g. some states are reporting both the total number of state and local employees covered rather than just the number of state employees. Unfortunately we have been unable to find a better data source that extends further back in time.

${ }^{24}$ These specifications are similar in spirit to specifications in papers by Lee (2008) and others, who employ a regression discontinuity design to estimate the partisan incumbency advantage. Note, however, that restricting attention to close elections does not help us identify a causal effect of the patronage system. Our reason for focusing on close elections is different, as described above. It is reassuring, however, to know that the results for the restricted samples are similar to those for the full sample, since these rely less on correctly specifying the underlying relationship between voter support and the probability of winning.

${ }^{25}$ Because there is overlap in the measure of the dependent variable across adjacent years, we suspect that the residuals will be serially correlated. Thus, we cluster the standard errors by state. This serial correlation is less likely to be a concern when we focus on close elections as there tends to be several years separating observations within each state.
} 
We study the period 1885 to 1995. Since there may be important changes in the political structure right before and after the civil service reforms, we exclude the six years directly before and after the adoption of the general civil service reform law in each state. ${ }^{26}$

As equation (1) makes clear, our strategy for identifying the effect of patronage is a differences-in-differences approach, exploiting the fact that different states adopted general civil service reforms at different times. Of course, this approach rests on the assumption that the timing of civil service reforms is exogenous to expected future election outcomes.

\subsection{Results}

We begin with a graphical analysis, shown in Figures $3 \mathrm{a}$ and $3 \mathrm{~b}$. These figures show binned averages of two outcome variables as a function of the winning party's margin in the lower house at time $t$. The outcome variable in Figure $3 \mathrm{a}$ is an indicator for whether the party that controlled the legislature at time $t$ also won control of the state legislature in each of the subsequent 8 years ( 4 elections) beginning at $t+1$. The outcome variable in Figure $3 \mathrm{~b}$ is the share of statewide offices won by the party in control at $t$ during the 8 years beginning at $t+1$. The figures show that winning full control by winning the lower house had a different effect on future electoral success elections before and after the introduction of civil service reforms. Note that in both figures, for the bins closest to the threshold, which cover margins of 0 to 7 percent, the incumbent party always does better under a patronage system than under a civil service system. This is consistent with the main predictions discussed above. In Figure 3b the incumbent party does better under a patronage system even for a broader range of margins.

Table 1 presents the main regression results. Each column corresponds to one of the four dependent variables described above. The top panel studies the full sample. The rows in this panel show specifications with different sets of regressors. The bottom panel only uses observations where the winner at $t$ won the lower house by a fairly close margin. Each row corresponds to a different threshold for determining close elections. Each entry shows the estimated coefficient on Patronage Dummy, with the estimated standard error below in

\footnotetext{
${ }^{26}$ Excluding these years also avoids any overlap of patronage and civil service in our dependent variables. The substantive findings are not affected if these years are kept in the sample.
} 
parentheses. The number of observations is shown in the last column.

To see what the coefficients mean, consider, for example, the first column and sixth row. The point estimate of 0.28 implies that when the winning party of a lower house election at $t$ has a seat share advantage of four percentage points or less, the probability that the winning party continues to control the state legislature over the next eight years is about 28 percent higher under patronage than under the civil service.

In virtually all cases the estimated coefficient on Patronage Dummy is statistically significant and substantively large, with the point estimates ranging from about 0.16 to about 0.34 in the bottom panel. Note also that in all columns, the estimated coefficient on Patronage Dummy falls as the threshold used to define close races increases - i.e., as increasingly lopsided cases are added. This probably reflects the fact that we are adding cases where one party has a non-trivial advantage in voter loyalty, so patronage per se is less important for winning. Importantly, patronage is not only correlated with future legislative victories, but also with winning control of statewide offices (columns 2 and 4). This is important because it indicates that the coefficients for the legislative dependent variables do not simply capture an effect of gerrymandering or malapportionment. Statewide offices are, by definition, not districted, so they cannot be gerrymandered or malapportioned.

Overall, then, the results in Table 1 are strongly consistent with the hypothesis that parties were able to use patronage to help win elections. As we would expect, the estimated coefficient on Patronage Dummy tends to be largest when comparing cases where state legislative election outcomes are close.

\subsection{Robustness Checks}

Table 2 presents a set of "placebo" tests. The structure is the same as in Table 1, but the dependent variables refer to elections prior to the election at time $t$, rather than elections after time $t$. Winning at time $t$ should have no systematic causal effect on winning prior to time $t$. In the first two columns of the table the dependent variable is defined in terms of legislative control (column 1) or statewide office victories (column 2) that occur between years $t-12$ and $t-5$. In columns 3 and 4 of the table the dependent variables cover control 
and victories for years $t-16$ and $t-9$. Note that we do not include the most recent past i.e., years $t-5$ and $t-1$ - because we use these years to define "entrenched incumbents" in the analyses below.

The estimated coefficients in Table 2 are uniformly lower than those in Table 1 and some are even negative, and none are statistically significant at the standard $5 \%$ level. A few of the coefficients are large - e.g., those in the last row of columns 1 and 2 - but we take comfort in the fact that the estimates are relatively unstable as we move from row to row within columns. In particular, none of the columns have consistently large coefficients. Thus, overall these results increase our confidence that the estimates in Table 1 are not just picking up something spurious - e.g., differential changes in voter partisanship across states that is correlated with civil service reform.

We also ran the regressions above including five additional variables. The first variable captures the "reapportionment revolution" due to Baker v. Carr and related Supreme Court decisions. Malapportionment is one potentially easy way for a party of remaining in power - it can create state legislative districts such that the areas where the supporters of the opposing party tend to live are under-represented and the areas where its supporters live are over-represented. The decision in Reynolds $v$. Sims (1964) made this practice illegal. We measure this simply with a post-1964 dummy variable. This variable also effectively captures the era of the "personal incumbency advantage." If individual incumbents have a large personal advantage, then the party that wins more seats at time $t$ may continue to win at time $t+1$, etc. simply because it has more incumbents, each of which has a personal advantage. Most previous work finds a large personal incumbency advantage emerging by the late 1960s. ${ }^{27}$ The second variable captures direct primary elections. Many progressive reformers argued that the direct primary would weaken the party machines. Under primaries, machine leaders would no longer have control over nominations, so that aspiring politicians would no be forced to work for the machine. We measure this with a dummy variable that is 1 for years when a state had mandatory primary elections and 0 otherwise. The third variable is an indicator for pre- and post- Hatch Act adoption and prior to civil service

\footnotetext{
${ }^{27}$ The results are very similar if we include a post-1970 dummy variable instead of the post-1964 dummy variable to capture the growth in personal incumbency advantage.
} 
reform. As discussed in section 2, the Hatch Act may have had dampening effect on the use of patronage by prohibiting certain state employees from engaging in election-related activities. $^{28}$ Finally, we include a dummy variable for the introduction of provisions allowing for collective bargaining by public sector employees. ${ }^{29}$

The results of these analyses are presented in Table 3. In none of these cases does the additional variable substantially affect the estimate of the coefficient on the Patronage Dummy variable. The coefficient on Patronage Dummy remains statistically significant in virtually all specifications, and the additional variable is never large or statistically significant itself.

\section{Entrenched vs. Non-entrenched Parties}

In this section we examine whether the electoral advantage from controlling the legislature under a patronage system is larger for parties with recent experience as the majority party. We refer to parties that have continuously been in power for disportionate amount of the years prior to an election as entrenched parties. While some scholars, such as Sorauf (1959), might find the claim that entrenched parties will have an additional electoral advantage under a patronge systsm as being intuitive and perhaps even obvious, the rationale underlying this claim is often not clearly articulated and, at least to our knowledge, there is no systematic evidence that this entrenched party advantage exists. Thus, we begin by discussing some of the factors that could lead entrenched parties to have an electoral advantage under a patronage system. We then present the specification and results.

\subsection{Theoretical Considerations}

An entrenched party typically enjoys an intrinsic electoral advantage over its opponents, due to factors such as imbalance in the distribution of ideological positions, policy preferences, or party attachments among voters. While this intrinsic advantage exists under both patronage and civil service systems, we present four factors that could theoretically

\footnotetext{
${ }^{28}$ The Hatch Act Dummy is 1 if a state is under patronage post-1940, and zero otherwise - so, state civil service is assumed to make the Hatch Act redundant. We also ran a separate specification with a simple post-1940 dummy variable and the results are similar to those reported in Table 3.

${ }^{29}$ The dates for the introduction of collective bargaining come from the NBER Public Sector Collective Bargaining Law Data Set.
} 
provide entrenched parties an electoral advantage under a patronage system relative to nonentrenched parties.

First, entrenched parties are likely to have a monetary resource advantage over other parties under a patronage system. By definition, an entrenched party will tend to be in power more often than other parties. If party organizations could extract part of their patronage appointees' salaries, then an entrenched party will be able to accumulate these resources over a longer time period compared to the weaker party. ${ }^{30}$

Second, entrenched parties are more likely to attract high quality employees - specifically, employees with electioneering talent. Suppose that the entrenched party is in power, say, $75 \%$ of the time, while the weaker party is only in power $25 \%$ of the time. In this situation the expected value of the same wage - the wage of the government job times the probability of holding the job - is three times as larger when offered by an entrenched party as compared to the weaker party. So, when bidding for talented workers, the entrenched party should win against the weaker party most if not all of the time.

Third, entrenched parties under patronage will benefit from having more opportunities for on-the-job learning. Electioneering is labor intensive, and effective party workers must develop networks of friends and acquaintances that can be persuaded to vote for the party and, in some cases, to donate time and money to get others to vote. Developing and maintaining these networks, and learning effective tools of persuasion, takes time and effort. Thus, since the entrenched party is in power more often than other parties, its workers should tend to have larger stocks of human capital than those of other parties. Furthermore, to the extent that acquiring electioneering skills is costly, supporters of the entrenched party have a stronger incentive to acquire such skills as they tend to have more opportunities to actually use this capital.

Finally, another human capital-related reason entrenched parties may benefit from patronage is that their appointees are likely to have acquired more experience at providing government services. Again, by definition, the entrenched party is in power more often than

\footnotetext{
${ }^{30}$ Sorauf (1956) found that nearly $80 \%$ of the patronage employees in Centre County, Pennsylvania, claimed to have made a campaign contribution to the party. A 1962 study of Utah found that 33\% of patronage employees made campaign contributions "regularly" or "sometimes, especially during campaigns," but only $7 \%$ of civil service employees did so (Gordon, et al., 1962).
} 
other parties, so under the patronage system its workers will, on average, have acquired more on-the-job human capital than those of the weaker party. To the extent that this experience leads to better provision of government services, voters may have a preference for the appointees of an entrenched party.

\subsection{Specification Issues}

For this analysis we use a specific criteria for whether a party is considered entrenched. For each state $s$, and each time $t$, a party is considered to be entrenched if it held control of the legislature in state $s$ following the elections at times $t-2$ and $t-1$ - i.e., the last four years. We require more than one term of legislative control to ensure that we are identifying relatively strong incumbents. ${ }^{31}$

In section 3 we found that the electoral advantage from legislative control in patronage systems is most pronounced when examining "close" elections. Thus, in this analysis we focus on cases where the seat margin in the lower election in state $s$ at time $t$ was relatively small. We employ the same specification used to estimate the coefficients in the lower panel of Table 1, but now we include a dummy variable for whether the party that wins the election at time $t$ is entrenched and an interaction term between this dummy variable and the Patronage Dummy variable. The results using the full sample and a specification similar to equation (1) are substantively very similar to our findings focusing on close elections. ${ }^{32}$ Our specification is:

$$
V_{s t}=\beta_{0}+\beta_{1} I_{s t} P_{s t}+\beta_{2} I_{s t}+\beta_{3} P_{s t}+\epsilon_{s t}
$$

where $V_{s t}$ is the election outcome under study from the point of view of the party that controls the legislature in state $s$ at time $t$. $I_{s t}$ is the Entrenched Party Dummy which is equal to 1 if the party winning control of the legislature in state $s$ at time $t$ also controlled the legislature for the previous four years and 0 otherwise. $P_{s t}$ is the Patronage Dummy variable

\footnotetext{
${ }^{31}$ We experimented with other definitions, based on spells of control lasting 3 and 4 terms. When we use three terms to defined entrenched parties the results are quite similar to those reported here. When we use four terms the point estimates are similar, but the standard errors are larger also so some of the estimated coefficients are no longer statistically significant at the $5 \%$ level.

${ }^{32}$ One reason for focusing on close elections is that by adding the Entrenched Dummy variable the number of interaction terms in specification controlling for seat shares is very large, raising concerns about multicollinearity issues especially when state and year fixed effects are also included.
} 
which is equal to 1 if state $s$ is operating under a patronage system at time $t$ and 0 otherwise. Note that $\beta_{2}$ is the relative electoral advantage enjoyed by the entrenched incumbent from holding a majority of the seats in house $j$ at time $t$, compared to the advantage enjoyed by a non-entrenched party under the civil service system. ${ }^{33}$ The main parameter of interest, $\beta_{1}$, is the relative electoral advantage enjoyed by the entrenched incumbent under the patronage system, which helps us capture both the relative advantage versus non-entrenched parties under patronage, $\beta_{2}$, and entrenched parties under civil service, $\beta_{3} \cdot{ }^{34}$ Given the arguments in the previous section, we expect $\beta_{1}$ to be positive.

The dependent variables are the same as in section 3 above, as is the time period studied. We run the regressions in the sub-sample of close lower house elections. The limits in winning margin for close elections are 4, 6 and 8 percent. The reasons for focusing on this subset of elections are discussed in Section 3.

\subsection{Results}

The results are shown in Table 4, which is similar in format to the lower panel of Table 1. As noted above, we only use observations where the winner at $t$ won control of the lower house by a close margin.

The results in Table 4 show that the difference in the probability of winning future elections between states under patronage and civil service largely reflects the advantage for entrenched incumbents under patronage. The estimated coefficient on the interaction term between the Patronage Dummy and the dummy for the entrenched incumbent winning control at time $t$ is substantively large and generally statistically significant. ${ }^{35}$ Consider, for example, the specification when using a $6 \%$ percent threshold in the seat share to estimate the probability of maintaining control for the eight subsequent years. The estimates imply that the probability of maintaining control of the state legislature under patronage is about 0.37 higher for the entrenched incumbent than for the non-entrenched party. The non-entrenched

\footnotetext{
${ }^{33}$ That is, $E[V \mid I=1, P=0]-E[V \mid I=0, P=0]=\beta_{0}+\beta_{2}-\beta_{0}=\beta_{2}$.

${ }^{34}$ This follows from: $(E[V \mid I=1, P=1]-E[V \mid I=0, P=1])-(E[V \mid I=1, P=0]-E[V \mid I=0, P=0])=$ $\left(\beta_{0}+\beta_{1}+\beta_{2}+\beta_{3}-\beta_{0}-\beta_{3}\right)-\left(\beta_{0}+\beta_{2}-\beta_{0}\right)=\beta_{1}$.

${ }^{35}$ In the bottom row, which includes the cases with margin of $2 \%$ or less, only one of the coefficients is significant. This is likely due to multicollinearity combined with the small number of observations.
} 
party does not seem to benefit from being under a patronage system. Furthermore, the entrenched party, if anything, is disadvantaged in states under a civil service system.

While not shown in Table 4 to conserve space, the estimates of the coefficient on the $P a$ tronage Dummy variable are not statistically significant in any specification when including the interaction term. The estimates are also significantly different from the coefficient on the interaction term in almost all specifications. This indicates that the non-entrenched parties did not significantly benefit from control of government under the patronage system, which is consistent with the theoretical arguments regarding why entrenched parties would be the main beneficiaries from a patronage system. ${ }^{36}$

\subsection{Entrenched Party Advantage in Close Elections Under Patronage}

We suspect that patronage is likely to be a particularly valuable resource for parties when there is a threat of losing an election. Thus, if patronage provides entrenched parties with an electoral advantage we might expect to observe a difference in the fraction of close elections they win before and after the introduction of general civil service reforms. The fraction should be lower under the civil service system. To examine whether such a pattern exists we compute the share of close election wins for entrenched parties under patronage versus civil service. We examine this for 5 winning margins in the lower house, 1, 2, 3, 4 and 5 percentage points.

Note that in general we expect some "sorting" in favor of entrenched parties except for very small windows around $50 \%$. This is simply due the fact that entrenched parties, on average, are likely to have more voter support. Suppose, for example, that the Democratic seat share in a state is normally distributed around 60 percent. Then there will automatically be more elections in the 50-55 percent window than in the 45-50 percent window. However, while we expect to see some sorting, we do not expect to see a large difference in entrenched parties' win margins between patronage and civil service regimes. ${ }^{37}$

\footnotetext{
${ }^{36}$ In addition, the estimated coefficient for the entrenched party is negative in all specifications, except when the dependent variable is statewide office wins over the next eight years, and statistically significant in some. This suggests that a party that has held power for a long period of time is more likely to lose power under civil service. This could, for example, be explained by regular swings in party popularity and reversion to the mean. If elections are competitive, then spells in power do not tend to be very long.

${ }^{37}$ Note in particular that the standard deviation of the seat share distribution is relatively similar under
} 
Table 5 shows the share of wins in close elections. Under patronage the share of wins for the entrenched party remains constant at about 75 percent. That is, the entrenched party is expected to win 3 out of 4 elections even when the elections are very close. Under civil service the entrenched parties have no advantage in winning very close elections. However, as expected, the share of wins does increase as we increase the margin of defining closeness. Thus, the anomaly is that the share of wins remain constant and high under patronage as we narrow the window for close elections. We also compared the share of wins in close elections for non-entrenched parties, and we do not find any electoral advantage in close races, either under patronage or civil service. If anything, parties with one term of legislative control tend to lose more close elections than they win under patronage. Given the small sample sizes, we cannot draw any clear conclusions, but the pattern is very different than for the entrenched parties under patronage.

These results are consistent with the idea that parties in control of patronage machines are able to "turn on" the party machine to win close elections and maintain legislative control. Turning on the party machine could imply two things. One is that the party is able to increase the amount of campaign resources raised when the election is expected to be close, and allocate these resources to key districts. Another possibility is electoral fraud - the party is simply cheating. We cannot determine which of these underlies the results in Table 5, or whether it is a mixture of both. We can say that entrenched parties were evidently no longer able to turn on the machine or engage in fraud to the same extent after the introduction of civil service.

\section{Conclusion}

Tammany Hall Boss William Tweed popularized the saying, "To the victor belongs the spoils." (Maranto and Johnson, 2007). Patronage has long been believed to be one of the "spoils" available to victorious political parties. While some of these spoils were probably consumed as "rents," some were probably used to maintain the parties' control of government - otherwise, they would miss out on future spoils. One of the motivations for civil service reforms was to eliminate such concentrations of resources in the hands of incumbents. Despite the two regimes: 17.6 under patronage and 16.1 under the civil service. 
this widespread perception, there has been little systematic evidence, at least for the U.S., that political parties have been able to utilize their control over patronage for their own electoral advantage.

The main contribution of this paper is to provide quantitative evidence that control of patronage increases the probability that the incumbent party will win future elections. Prior to the introduction of state civil service reform, a party which won full control of the state legislature would significantly increase the likelihood of winning not only the next election but also several subsequent elections. This electoral advantage from controlling the state legislature is no longer present after states enacted legislation to expand the number of state employees covered under civil service.

While our analysis points to civil service reform as a means of weakening partisan control of patronage, other changes occurring during our time period may also have potentially weakened the impact of patronage on electoral outcomes. In section 3, we check the robustness of our findings against alternative explanations, such as the rising personal vote and the "reapportionment revolution." We also examine the influence of two additional factors which may have affected the changing impact of control of the state legislature on future electoral success - the Hatch Act and collective bargaining by state employees.

Another contribution in this paper is to provide evidence that being an entrenched party yields additional electoral benefits from gaining control of patronage. We outline some theoretical reasons why the benefits from control of patronage may be related to the length of time the party is in power.

Finally, we also began to explore the mechanisms through which entrenched parties have an advantage over non-entrenched parties. This is another potential area in which we intend to extend our analysis. Clearly, however, much more work on mechanisms remains to be done.

One potential concern with our analysis which we intend to investigate in future research is the non-random nature of when civil service reforms were enacted. If the civil service reforms were in part motivated by the changes in electoral outcomes, our estimates of the political impact of the patronage system could suffer from an endogeneity bias. Some 
preliminary robustness checks - e.g. limiting the sample to 30 years before and after the introduction of the civil service - provide little evidence that our findings simply reflect an underlying trend that affects both electoral outcomes and the timing of civil service reform. However, further analysis of the passage of state civil service reforms is necessary. Careful case studies would be especially useful at this point.

Our findings also provide some insight into why state party organizations have weakened over time. Our results are consistent with the idea that parties in control of the legislature may have used patronage to cultivate a loyal partisan electoral base. Civil service reforms which removed this core group of party supporters beholden to the incumbent party for their employment weakened the ability of political parties to organize their supporters within the electorate. Further investigation of this connection between civil service reform and the strength of party organization is another area which we plan to explore in future research. 


\section{References}

Ansolabehere, Stephen, and James M. Snyder, Jr. 2002. "Incumbency Advantages in the States: An Analysis of State and Federal Offices, 1942 - 2000." Election Law Journal 1: $315-338$.

Aronson, Albert H. 1979. "State and Local Personnel Administration." In Classics of Public Personnel Policy, edited by Frank J. Thompson. Oak Park IL: Moore Publishing Company.

Berry, Curtis R. 2000. "Developments in Personnel/Human Resources Management in State Government." In Handbook of State Government Administration, edited by John J. Gargan. New York: Marcel Dekker, Inc.

Carpenter, William Seal, and Paul Tutt Stafford. 1936. State and Local Government in the United States. New York: F.S. Crofts and Co.

Civil Service Assembly of the United States and Canada. 1940. "Civil Service Agencies in the United States: A 1940 Census." Pamphlet No. 16.

Cleary, Robert E. 1960. "Gubernatorial Leadership and State Policy on Desegregation in Public Higher Education." Phylon 27: 165-170.

Conference Committee on the Merit System. 1926. "The Personnel Problem in the Public Service. Preliminary Report of the Conference Committee on the Merit System." Public Personnel Studies 4(1).

Dubin, Michael J. 2007. Party Affiliations in the State Legislatures: A Year by Year Summary, 1796-2006. Jefferson, NC: McFarland and Company, Inc.

Gordon, Oakley, Reed Richardson, and J. D. Williams. 1962. Personnel Management in Utah State Government Research Monograph No. 6, Institute of Government, University of Utah.

Holley, Carl E. 1986. "Carl E. Bailey, the Merit System, and Arkansas Politics, 1936-1939." Arkansas Historical Quarterly 45: 291-320.

Jacob, Herbert, and Kenneth N. Vines. Politics in the American States. Boston: Little, Brown, and Company.

Jewell, Malcolm E. 1962. The State Legislature: Politics and Practice. New York: Random House.

Johnston, Michael. 1979. "Patrons and Clients, Jobs and Machines: A Case Study of the Uses of Patronage." The American Political Science Review 73(2): 385-398.

Kaufman, Herbert. 1956. "Emerging Conflicts in the Doctrines of Public Administration." American Political Science Review 50: 1057-1073.

Kearney, Richard C. 2001. Labor Relations in the Public Sector. New York: Marcel Dekker, Inc. 
Keefe, William J. 1966. "The Functions and Powers of the State Legislature." In State Legislatures in American Politics, edited by Alexander Heard. Englewood Cliffs, NJ: Prentice Hall.

Key, V.O. 1964. Politics, Parties, and Pressure Groups. Fifth Edition. New York: Thomas Y. Crowell Company.

Klingner, Donald E. 2006. "Societal Values and Civil Service Systems in the United States." In Civil Service Reform in the States: Personnel Policy and Politics at the Subnational Level, edited by J. Edward Kellough and Lloyd G. Nigro. Albany, NY: State University of New York Press.

Larson, James E. 1968. "South Carolina Legislature." In Southeastern State Legislatures in American Politics. Atlanta, GA: Emory University School of Law.

Lee, David. 2008. "Randomized Experiments from Non-random Selection in U.S. House Elections." Journal of Econometrics 142(2): 675-697.

Maranto, Robert, and Jeremy Johnson. 2007. "Bringing Back Boss Tweed: Could At-Will Employment Work in State and Local Government and, If So, Where?" In American Public Service: Radical Reform and the Merit System, edited by James S. Bowman and Jonathan P. West. Boca Raton, FL: CRC PRess.

Merriam, Charles E., and Harold F. Gosnell. 1949 The American Party System. New York: The Macmillan Company.

Nixon, H. C. 1948. "The Southern Legislature and Legislation." Journal of Politics 10: 410-417.

Pollock, James K. 1937. "The Cost of the Patronage System." The Annals of the American Academy of Political and Social Science 189: 29-34.

Roady, Elston E., and Manning J. Dauer. 1968. "The Florida Legislature." In Southeastern State Legislatures in American Politics. Atlanta, GA: Emory University School of Law.

Sorauf, Frank J. 1956. "State Patronage in a Rural County." American Political Science Review 50: (4): 1046-1056.

Sorauf, Frank J. 1959. "Patronage and Party." Midwest Journal of Political Science 3(2): 115-126.

Trounstine, Jessica. n.d. "Modern Machines: Information, Patronage, and Incumbency in Local Elections." Unpublished manuscript.

Tucker, Joseph B. 1969. "The Administration of a State Patronage System: The Democratic Party in Illinois." Western Political Quarterly 22: 79-84.

Wilson, James Q. 1961. "The Economy of Patronage." Journal of Political Economy 69 (4): 369-380.

Zink, Harold. 1951. Government and Politics in the United States. New York: The MacMillan Co. 


\begin{tabular}{|c|c|c|c|c|c|}
\hline Specification and Sample & $\begin{array}{l}\text { Leg Cntrl } \\
\text { Next } 8 \text { Yrs }\end{array}$ & $\begin{array}{l}\text { SW Wins } \\
\text { Next } 8 \text { Yrs }\end{array}$ & $\begin{array}{l}\text { Leg Cntrl } \\
\text { Next } 4 \text { Yrs }\end{array}$ & $\begin{array}{l}\text { SW Wins } \\
\text { Next } 4 \text { Yrs }\end{array}$ & \# Obs. \\
\hline $\begin{array}{l}\text { linear controls, no FE } \\
\text { full sample }\end{array}$ & $\begin{array}{c}0.219 \\
(0.073)\end{array}$ & $\begin{array}{c}0.214 \\
(0.052)\end{array}$ & $\begin{array}{c}0.181 \\
(0.056)\end{array}$ & $\begin{array}{c}0.232 \\
(0.054)\end{array}$ & 974 \\
\hline $\begin{array}{l}\text { full controls, no FE } \\
\text { full sample }\end{array}$ & $\begin{array}{c}0.433 \\
(0.126)\end{array}$ & $\begin{array}{c}0.242 \\
(0.097)\end{array}$ & $\begin{array}{c}0.414 \\
(0.123)\end{array}$ & $\begin{array}{c}0.233 \\
(0.097)\end{array}$ & 974 \\
\hline $\begin{array}{l}\text { full controls, state \& year FE } \\
\text { full sample }\end{array}$ & $\begin{array}{c}0.552 \\
(0.149)\end{array}$ & $\begin{array}{c}0.213 \\
(0.119)\end{array}$ & $\begin{array}{c}0.462 \\
(0.155)\end{array}$ & $\begin{array}{c}0.133 \\
(0.115)\end{array}$ & 974 \\
\hline $\begin{array}{l}\text { no controls, no FE } \\
\text { Lower House margin } \leq 8\end{array}$ & $\begin{array}{c}0.165 \\
(0.055)\end{array}$ & $\begin{array}{c}0.158 \\
(0.039)\end{array}$ & $\begin{array}{c}0.159 \\
(0.061)\end{array}$ & $\begin{array}{c}0.176 \\
(0.043)\end{array}$ & 267 \\
\hline $\begin{array}{l}\text { no controls, no FE } \\
\text { Lower House margin } \leq 6\end{array}$ & $\begin{array}{c}0.232 \\
(0.064)\end{array}$ & $\begin{array}{c}0.173 \\
(0.047)\end{array}$ & $\begin{array}{c}0.192 \\
(0.071)\end{array}$ & $\begin{array}{c}0.179 \\
(0.052)\end{array}$ & 190 \\
\hline $\begin{array}{l}\text { no controls, no FE } \\
\text { Lower House margin } \leq 4\end{array}$ & $\begin{array}{c}0.283 \\
(0.079)\end{array}$ & $\begin{array}{c}0.176 \\
(0.058)\end{array}$ & $\begin{array}{c}0.311 \\
(0.084)\end{array}$ & $\begin{array}{c}0.212 \\
(0.063)\end{array}$ & 122 \\
\hline $\begin{array}{l}\text { no controls, no FE } \\
\text { Lower House margin } \leq 2\end{array}$ & $\begin{array}{c}0.326 \\
(0.124)\end{array}$ & $\begin{array}{c}0.247 \\
(0.080)\end{array}$ & $\begin{array}{c}0.352 \\
(0.130)\end{array}$ & $\begin{array}{c}0.234 \\
(0.091)\end{array}$ & 53 \\
\hline
\end{tabular}

Cell entries are the estimated coefficients on the Patronage variable. Robust standard errors in parentheses. In rows 1-3 standard errors are clustered by state. Full controls are a 3rd-order polynomial of the Margin variable, interacted with the Patronage variable. 


\begin{tabular}{|c|c|c|c|c|c|}
\hline \multicolumn{6}{|c|}{ Table 2: Placebo Regressions } \\
\hline Specification and Sample & $\begin{array}{l}\text { Leg Cntrl } \\
\text { Previous } \\
\text { 5-12 Yrs }\end{array}$ & $\begin{array}{l}\text { SW Wins } \\
\text { Previous } \\
5-12 \text { Yrs }\end{array}$ & $\begin{array}{c}\text { Leg Cntrl } \\
\text { Previous } \\
\text { 9-16 Yrs }\end{array}$ & $\begin{array}{l}\text { SW Wins } \\
\text { Previous } \\
\text { 9-16 Yrs }\end{array}$ & \# Obs. \\
\hline $\begin{array}{l}\text { linear controls, no FE } \\
\text { full sample }\end{array}$ & $\begin{array}{c}0.067 \\
(0.075)\end{array}$ & $\begin{array}{c}0.104 \\
(0.053)\end{array}$ & $\begin{array}{l}-0.042 \\
(0.073)\end{array}$ & $\begin{array}{c}0.082 \\
(0.053)\end{array}$ & 974 \\
\hline $\begin{array}{l}\text { full controls, no FE } \\
\text { full sample }\end{array}$ & $\begin{array}{c}0.113 \\
(0.109)\end{array}$ & $\begin{array}{c}0.176 \\
(0.076)\end{array}$ & $\begin{array}{l}-0.167 \\
(0.127)\end{array}$ & $\begin{array}{c}0.121 \\
(0.069)\end{array}$ & 974 \\
\hline $\begin{array}{l}\text { controls, state \& year FE } \\
\text { full sample }\end{array}$ & $\begin{array}{c}0.145 \\
(0.170)\end{array}$ & $\begin{array}{c}0.153 \\
(0.110)\end{array}$ & $\begin{array}{l}-0.101 \\
(0.172)\end{array}$ & $\begin{array}{c}0.127 \\
(0.107)\end{array}$ & 974 \\
\hline $\begin{array}{l}\text { no controls, no FE } \\
\text { Lower House margin } \leq 8\end{array}$ & $\begin{array}{c}0.003 \\
(0.058)\end{array}$ & $\begin{array}{c}0.082 \\
(0.040)\end{array}$ & $\begin{array}{l}-0.089 \\
(0.057)\end{array}$ & $\begin{array}{c}0.067 \\
(0.038)\end{array}$ & 267 \\
\hline $\begin{array}{l}\text { no controls, no FE } \\
\text { Lower House margin } \leq 6\end{array}$ & $\begin{array}{c}0.034 \\
(0.070)\end{array}$ & $\begin{array}{c}0.081 \\
(0.047)\end{array}$ & $\begin{array}{l}-0.108 \\
(0.068)\end{array}$ & $\begin{array}{c}0.066 \\
(0.041)\end{array}$ & 190 \\
\hline $\begin{array}{l}\text { no controls, no FE } \\
\text { Lower House margin } \leq 4\end{array}$ & $\begin{array}{l}-0.005 \\
(0.086)\end{array}$ & $\begin{array}{c}0.061 \\
(0.058)\end{array}$ & $\begin{array}{l}-0.205 \\
(0.082)\end{array}$ & $\begin{array}{c}0.047 \\
(0.052)\end{array}$ & 122 \\
\hline $\begin{array}{l}\text { no controls, no FE } \\
\text { Lower House margin } \leq 2\end{array}$ & $\begin{array}{c}0.106 \\
(0.132)\end{array}$ & $\begin{array}{c}0.161 \\
(0.092)\end{array}$ & $\begin{array}{l}-0.063 \\
(0.123)\end{array}$ & $\begin{array}{c}0.105 \\
(0.079)\end{array}$ & 53 \\
\hline
\end{tabular}

Cell entries are the estimated coefficients on the Patronage variable. Robust standard errors in parentheses. In rows 1-3 standard errors are clustered by state. Controls are 3rd-order polynomials of the Margin variable, interacted with the Patronage variable. 


\begin{tabular}{|l|c|c|c|c|c|}
\hline \multicolumn{5}{|c|}{ Table 3: Including Additional Control Variables } \\
\hline \multicolumn{5}{|c|}{ Dep. Var. = Legislative Control Next 8 Years } \\
\hline & \multicolumn{5}{|c|}{ Added Control Variable } \\
\hline Specification and Sample & Post-1964 & Primary & Hatch Act & Coll Barg & \#Obs. \\
\hline linear controls, no FE & 0.266 & 0.229 & 0.226 & 0.239 & 974 \\
full sample & $(0.072)$ & $(0.082)$ & $(0.082)$ & $(0.075)$ & \\
full controls, no FE & 0.479 & 0.447 & 0.435 & 0.452 & 974 \\
full sample & $(0.121)$ & $(0.136)$ & $(0.129)$ & $(0.121)$ & \\
full controls, state \& year FE & 0.552 & 0.564 & 0.451 & 0.551 & 974 \\
full sample & $(0.149)$ & $(0.150)$ & $(0.163)$ & $(0.152)$ & \\
\hline no controls, no FE & 0.130 & 0.178 & 0.190 & 0.134 & 267 \\
Lower House margin $\leq 8$ & $(0.066)$ & $(0.066)$ & $(0.062)$ & $(0.063)$ & \\
no controls, no FE & 0.218 & 0.247 & 0.274 & 0.223 & 190 \\
Lower House margin $\leq 6$ & $(0.073)$ & $(0.078)$ & $(0.072)$ & $(0.071)$ & \\
no controls, no FE & 0.280 & 0.354 & 0.314 & 0.270 & 122 \\
Lower House margin $\leq 4$ & $(0.088)$ & $(0.093)$ & $(0.089)$ & $(0.088)$ & \\
no controls, no FE & 0.340 & 0.418 & 0.459 & 0.255 & 53 \\
Lower House margin $\leq 2$ & $(0.133)$ & $(0.161)$ & $(0.138)$ & $(0.140)$ & \\
\hline
\end{tabular}

Cell entries are the estimated coefficients on the Patronage variable. Robust standard errors in parentheses. In rows 1-3 standard errors are clustered by state. Full controls are a 3rd-order polynomial of the Margin variable, interacted with the Patronage variable. 


\begin{tabular}{|c|c|c|c|c|c|}
\hline Specification and Sample & $\begin{array}{l}\text { Leg Cntrl } \\
\text { Next } 8 \text { Yrs }\end{array}$ & $\begin{array}{l}\text { SW Wins } \\
\text { Next } 8 \text { Yrs }\end{array}$ & $\begin{array}{l}\text { Leg Cntrl } \\
\text { Next } 4 \text { Yrs }\end{array}$ & $\begin{array}{l}\text { SW Wins } \\
\text { Next } 4 \text { Yrs }\end{array}$ & \# Obs. \\
\hline $\begin{array}{l}\text { no controls, no FE } \\
\text { Lower House margin } \leq 8\end{array}$ & $\begin{array}{c}0.319 \\
(0.107)\end{array}$ & $\begin{array}{c}0.168 \\
(0.076)\end{array}$ & $\begin{array}{c}0.447 \\
(0.118)\end{array}$ & $\begin{array}{c}0.245 \\
(0.085)\end{array}$ & 267 \\
\hline $\begin{array}{l}\text { no controls, no FE } \\
\text { Lower House margin } \leq 6\end{array}$ & $\begin{array}{c}0.374 \\
(0.123)\end{array}$ & $\begin{array}{c}0.198 \\
(0.093)\end{array}$ & $\begin{array}{c}0.599 \\
(0.133)\end{array}$ & $\begin{array}{c}0.333 \\
(0.101)\end{array}$ & 190 \\
\hline $\begin{array}{l}\text { no controls, no FE } \\
\text { Lower House margin } \leq 4\end{array}$ & $\begin{array}{c}0.272 \\
(0.155)\end{array}$ & $\begin{array}{c}0.189 \\
(0.114)\end{array}$ & $\begin{array}{c}0.471 \\
(0.162)\end{array}$ & $\begin{array}{c}0.344 \\
(0.124)\end{array}$ & 122 \\
\hline $\begin{array}{l}\text { no controls, no FE } \\
\text { Lower House margin } \leq 2\end{array}$ & $\begin{array}{c}0.381 \\
(0.244)\end{array}$ & $\begin{array}{c}0.114 \\
(0.174)\end{array}$ & $\begin{array}{c}0.623 \\
(0.244)\end{array}$ & $\begin{array}{c}0.133 \\
(0.195)\end{array}$ & 53 \\
\hline
\end{tabular}

Cell entries are the estimated coefficients on the Patronage variable interacted with the Entrenched variable. Robust standard errors in parentheses. 


\begin{tabular}{|c|c|c|}
\hline \multicolumn{3}{|c|}{ Table 5: Sorting in Close Elections } \\
For Entrenched Parties, 1885-1995 \\
\hline Lower House Margin & Patronage & Civil Service \\
\hline $1 \%$ & $70.0(10)$ & $44.4(9)$ \\
$2 \%$ & $76.2(21)$ & $53.8(26)$ \\
$3 \%$ & $77.1(35)$ & $61.5(39)$ \\
$4 \%$ & $76.6(47)$ & $66.0(50)$ \\
$5 \%$ & $76.7(60)$ & $70.0(60)$ \\
\hline
\end{tabular}




\begin{tabular}{|l|c|c|c|c|c|}
\hline \multicolumn{5}{|c|}{ Table A1: Patronage and Election Outcomes 1885-1995 } \\
(Governor Included in Defining Control) \\
\hline \multirow{2}{*}{ Specification and Sample } & Leg Cntrl & SW Wins & Leg Cntrl & SW Wins & \\
& Next 8 Yrs & Next 8 Yrs & Next 4 Yrs & Next 4 Yrs & \# Obs. \\
\hline no controls, no FE & 0.163 & 0.123 & 0.252 & 0.087 & 140 \\
Lower House margin $\leq 8$ & $(0.057)$ & $(0.052)$ & $(0.077)$ & $(0.057)$ & \\
no controls, no FE & 0.291 & 0.181 & 0.269 & 0.117 & 95 \\
Lower House margin $\leq 6$ & $(0.069)$ & $(0.065)$ & $(0.092)$ & $(0.071)$ & \\
no controls, no FE & 0.343 & 0.207 & 0.352 & 0.179 & 65 \\
Lower House margin $\leq 4$ & $(0.081)$ & $(0.076)$ & $(0.106)$ & $(0.083)$ & \\
\hline
\end{tabular}

Cell entries are the estimated coefficients on the Patronage variable. Robust standard errors in parentheses. 
Figure 1

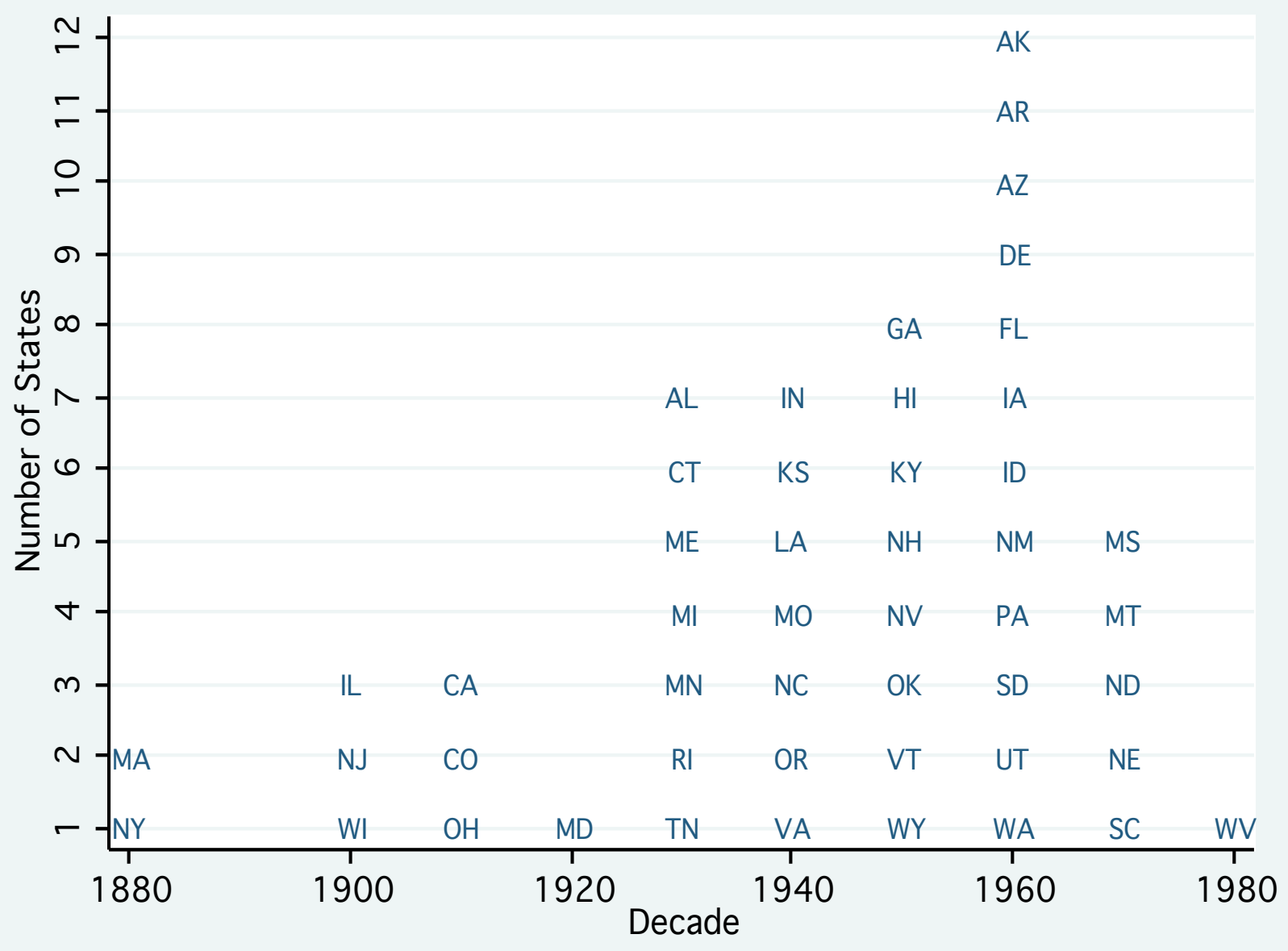


Figure 2

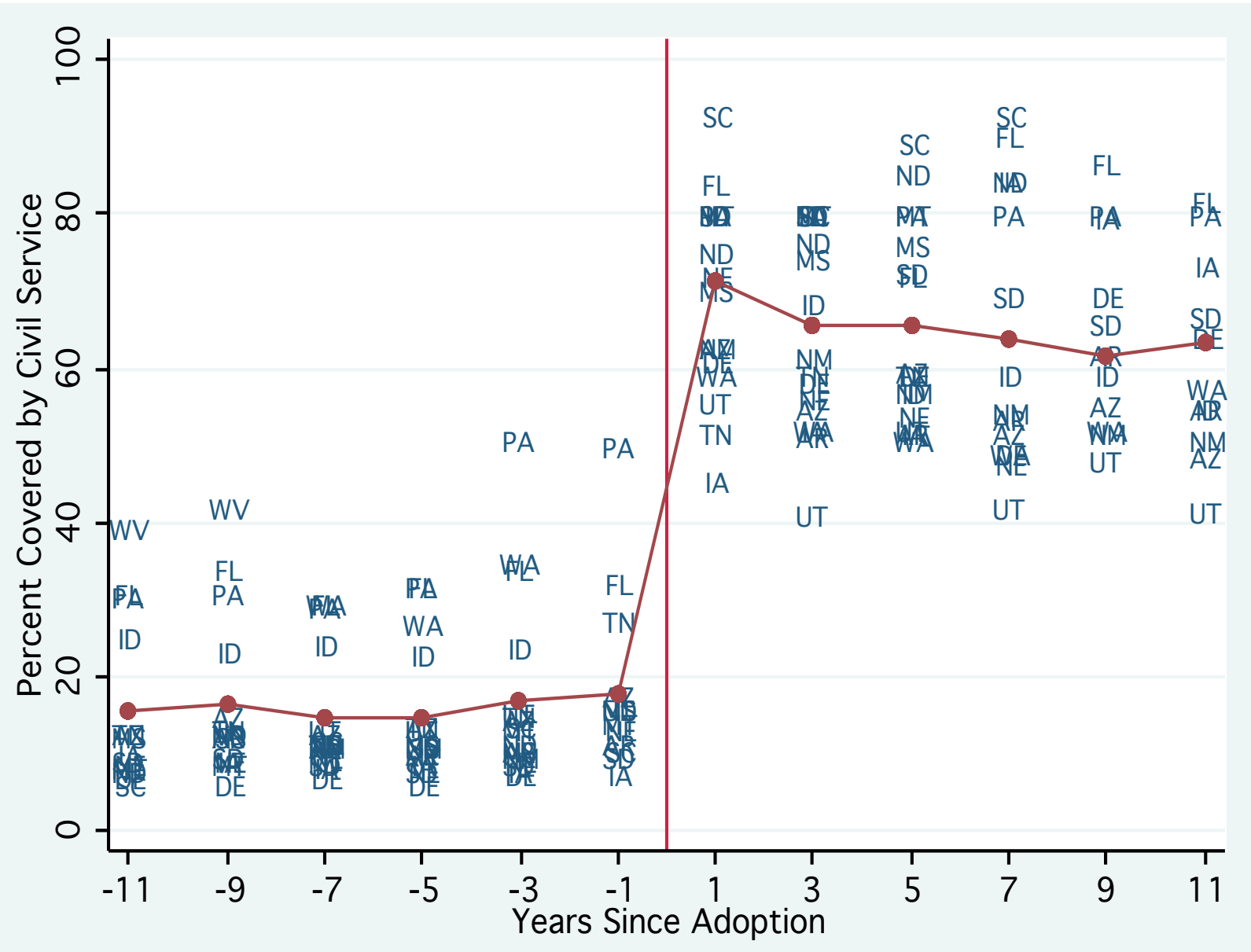


Figure 3a

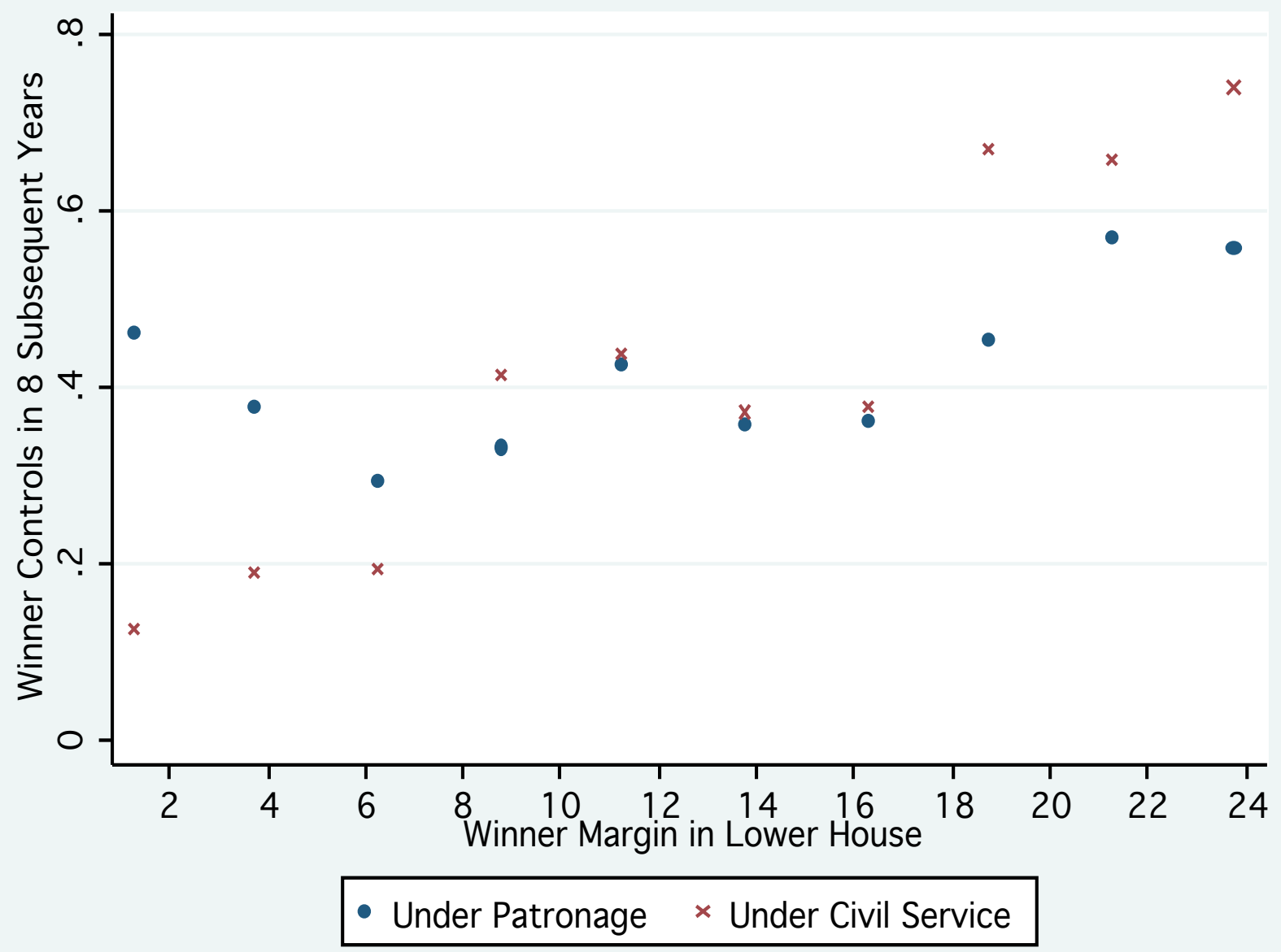


Figure 3b

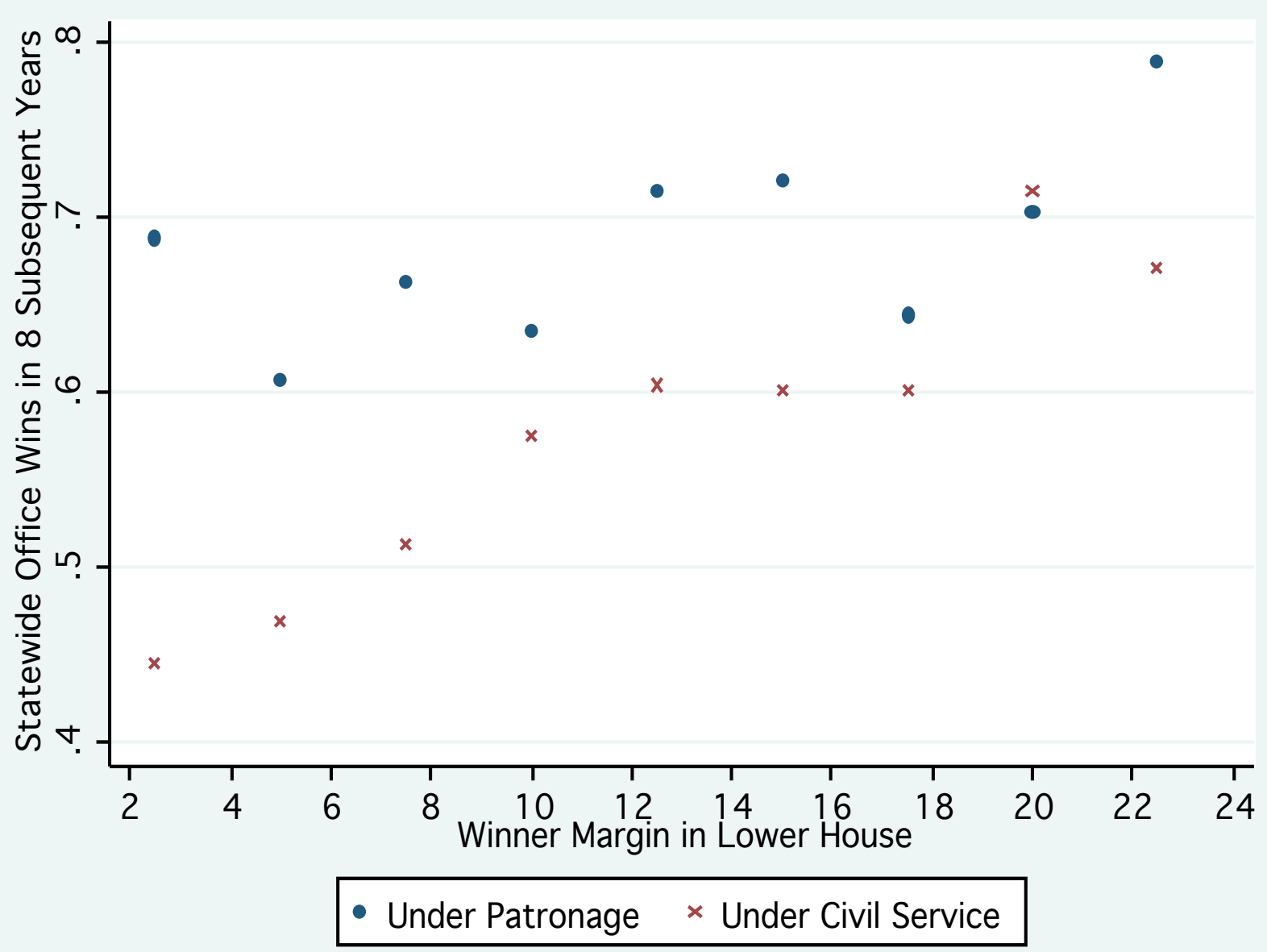

